\title{
Evaluation of Thermal Endurance Characteristics of Hard Polyurethane Foams by Dynamic Compression Modulus
}

\author{
Hiromasa ADACHI and Teruo HASEGAWA \\ Nagoya Municipal Industrial Research Institute, \\ 3-4-41, Rokuban, Atsuta-ku, Nagoya 456-0058, Japan
}

\begin{abstract}
For evaluation of thermal endurance in foamed plastics, temperature and time characteristics of compression dynamic modulus of four hard polyurethane foams were investigated by the dynamic viscoelastic measurements. Compression dynamic modulus of each polyurethane foams lessened gradually with time, probably due to a decrease of inner pressure of closed-cell, which influenced stiffness of foam skeletons. Logarithm of time $t$, at which the compression dynamic modulus came to be $50 \%$ of its initial value at the beginning of the dynamic measurement has been found to be a linear function of reciprocal of the absolute temperature $T^{-1}$. Thermal endurance characteristics can be evaluated from the linear relations between $\log t$ and $T^{-1}$.

Key Words: Polyurethane foam / Plastic foam / Dynamic modulus / Viscoelastic measurement / Thermal endurance characteristics
\end{abstract}

\section{硬質ポリウレタンフォームにおける動的圧縮弾性率による耐熱性の評価}

足立 廣正, 長谷川 照夫

(原稿受理 : 2003年9月 3 日)

1. 緒言

硬質ポリウレタンフォーム ${ }^{1,2}$ は高強度で断熱性に優れてい るため船舶，車両，冷凍・冷蔵庫倉庫などに使われているが， 最近では自動車の補強材 3 ,4) や宇宙構造物の構造部材5)への適 用にみられるように構造材として用いられることが多く なった．硬質ポリウレタンフォームを構造材として使用する 上で弾性率は重要な物性值であるが, 十分検討されていない のが現状である．著者らのは硬質ポリウレタンフォームにつ いて, 動的粘弾性パラメータの一つである動的弾性率はかさ 密度, 強度と良好な正の相関関係にあり, 動的弾性率が品質 管理における評価指標として有効であることを明らかにし てきた. 次に, 気泡破壊前後の硬質ポリウレタンフォームの 動的弾性率と静的弾性率とを比較して, 気泡破壊前において 動的弾性率は静的弾性率より大きいが気泡破壊後において 座屈による非線形現象のため動的弾性率は静的弾性率より 小さくなることがわかった.7)また，スケルトン（骨格）の曲 げを考慮した二次元モデルに有限要素法を適用して動的圧 縮弾性率, 静的圧縮弾性率を推定できること, 周波数温度換 算則が成立することを明らかにした. ${ }^{8}$

高分子材料において動的粘弾性測定器によって求められ る動的粘弾性パラメータである動的弾性率, 損失弾性率, 損 失正接は吸音性, 制振性, 衝撃吸収性, ころがり摩擦特性と

名古屋市工業研究所

† 456-0058 名古屋市熱田区六番 3-4-41
密接な関係があるといわれており ${ }^{9)}$, 損失正接を含めた線形 粘弾性と疲労，破壊挙動と結びつける研究10,11) もなされてい る. 邸ら ${ }^{12,13)}$ は高分子材料の高次構造と動的粘弾性パラメー タである動的弾性率，損失正接により疲労破損の進行する過 程を解析することにより耐久性に関する疲労破壊の評価を 行った. また, 石坂ら ${ }^{14)}$ は一方向炭素絨維/エポキシ複合材料 の吸湿挙動を動的粘弾性パラメータで評価した. 大西 ${ }^{15)}$ は自 動車用ゴム部品であるパワーステアリングホースと自動変 速機用オイルクーラーホースの熱による劣化について検討 し, 前者は内層ゴムの伸び，後者は補強系の強度が耐久時間 とともに低下し相関があることを明らかにした後, 各温度に ついて限界值まで低下する時間を算出し, その時間の対数と 絶対温度の逆数の線図である温度寿命線図を作成して, 寿命 予測を行った．著者ら ${ }^{16)}$ はビーズ法ポリスチレンフォームに おける動的弾性率の時間特性について時間特性が変化する 温度領域の動的弾性率が $10,20 \%$ 低下する時間を算出し，そ の時間の常用対数と絶対温度の逆数とは正の直線関係にあ ることを明らかにした．本研究では硬質ポリウレタンフォー ムの動的弾性率の時間特性を明らかにしてビーズ法ポリス チレンフォームの場合と同様に動的弾性率による耐熱性の 評価方法について検討した.

\section{2. 実験}

ポリウレタンフォームの製造では，ポリオールとイソシア 
ナートとの反応によりポリウレタンを生成させると同時に, イソシアナートと水との反応で発生した炭酸ガスを利用し てフォームとする. 4 種類の試料の物性をTable Iに示す. 測定 した硬質ポリウレタンフォームはイノアックコーポレー ション侏製 “フォームライト” で，4種類の試料は発泡剂の 量を変えることにより物性值が異なったものである. 引張強 さはJISA9511-1995にあるように, (株島津製作所製オートグラ フにより試験速度 $20 \mathrm{~mm} / \mathrm{min} て ゙$ 試験片を引張り, 荷重一伸び線 図より切断に至るまでの最大荷重を試験片の元の断面積で 割ったものである。圧縮強さはJISK7220-1995にあるように, 株)島津製作所製オートグラフにより試験速度 $10 \mathrm{~mm} / \mathrm{min}$ で試 験片を圧縮し, 荷重一圧縮線図より降伏に至るまでの最大荷 重を試験片の元の断面積で割ったものである. 空孔率は, フォーム密度と固体部分のウレタン密度より求めた.

$$
\nu=1-\rho 0 / \rho
$$

ここで $\rho_{0}$ はフォーム密度， $\rho$ はウレタン密度を表わす.

粘弾性測定器（侏レオロジ社製DVE-V4）により複素弾性 率の実数部である動的弾性率 $E^{\prime}$ を求めたが, 測定条件は周波 数 $10 \mathrm{~Hz}$, 振動振幅 $30 \mu \mathrm{m}$, 静的ひずみ $5 \%$ 以内である. 縦 $13 \mathrm{~mm}$, 横 $13 \mathrm{~mm}$, 厚さ $10 \mathrm{~mm}$ の四角柱の試料に対して圧縮用の治具を 使用し，下の円盤状の治具上に試料を置いてから上の円盤状 の治具を下げて測定した. 以下において圧縮モードと表現 する.

\section{3. 結果と考察}

Fig.1にフォーム試料の圧縮モードにおける動的弾性率の 時間特性を示す. なお, 周波数は $10 \mathrm{~Hz}$, 振動振幅は $30 \mu \mathrm{m}$, 温 度は240 $290^{\circ} \mathrm{C}$, サンプリング時間間隔は $1 \mathrm{~min}$ である. $240^{\circ} \mathrm{C}$ において Sample 2, 3の時間依存性はほとんどないが, 温度が 高くなるほど動的弾性率の時間に対する低下率は大きくな り, 特にSample 1，4のフォーム試料において $240 \sim 260^{\circ} \mathrm{C} に お ~$ ける低下率が大きい. Sample 1, 4のフォーム試料において 240 $260^{\circ} \mathrm{C}$ では $10 \mathrm{~min}$ 以内に動的弾性率の時間に対する低下 率が大きく変わり, 小さくなる. $290^{\circ} \mathrm{C}$ におけるすべての フォーム試料において測定開始から $25 \mathrm{~min}$ 以内で測定不能に なった後徐々に収縮していき, 最後は体積が $1 / 3$ 以下まで収縮 して黒く変色する. フォームの気泡構造は気泡を支える固体 部分のスケルトン（骨格）と気泡を包み込む薄い膜から成っ ていて, 当フォーム試料のような硬質ポリウレタンフォーム は気泡の薄膜が閉じている独立気泡である．圧縮荷重を受け たときの抵抗をスケルトンの変形に対する抵抗と気泡部の 圧縮に対する抵抗とに分けた場合, 静的ひずみおよび動的ひ ずみ振幅も小さいので気泡自体の圧縮に対する抵抗は考慮 する必要はなく, 独立気泡の内圧の影響をうけたスケルトン の変形に対する抵抗を考慮する必要がある．時間につれて一 部の気泡の薄膜が破れて気泡の内圧が下がり， スケルトンの 変形に対する抵抗が小さくなるため動的弾性率が徐々に小 さくなると考えられる. 空孔率の大きいSample 1 と空孔率の 小さいSample 4 の時間特性が比較的よく似ていることから空 孔率の大小のみがスケルトンの変形に対する抵抗の変化に 関係しているとはいえない.

Fig.1におけるフォーム試料の動的弾性率の時間特性にお
いて測定開始時間から動的弾性率が $10 ， 20 ， 50 \%$ 低下寸る時 間を $t \min$ と ，大西 ${ }^{13)}$ が行った寿命予測と同様にその時間の 対数と絶対温度の逆数との関係である温度寿命線図を作成 した. Fig. 2 は $t$ の常用対数 $\log t$ と絶対温度 $(T)$ の逆数との関係

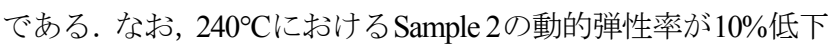
する值, Sample 2, 3 の動的弾性率が $20 \%$ 低下する值, Sample 3

Table I Physical properties of samples.

\begin{tabular}{llccc}
$\begin{array}{l}\text { Sample } \\
\text { code }\end{array}$ & $\begin{array}{c}\text { Foam } \\
\text { density } \\
\left(\mathrm{kg} / \mathrm{m}^{3}\right)\end{array}$ & $\begin{array}{c}\text { Tensile } \\
\text { strength } \\
(\mathrm{MPa})\end{array}$ & $\begin{array}{c}\text { Compression } \\
\text { strength } \\
(\mathrm{MPa})\end{array}$ & Porosity \\
\hline 1 & 50 & 0.71 & 0.42 & 0.958 \\
2 & 60 & 0.76 & 0.54 & 0.950 \\
3 & & & & \\
4 & & 1.04 & 0.70 & 0.933 \\
4 & 90 & 1.26 & 0.92 & 0.925
\end{tabular}

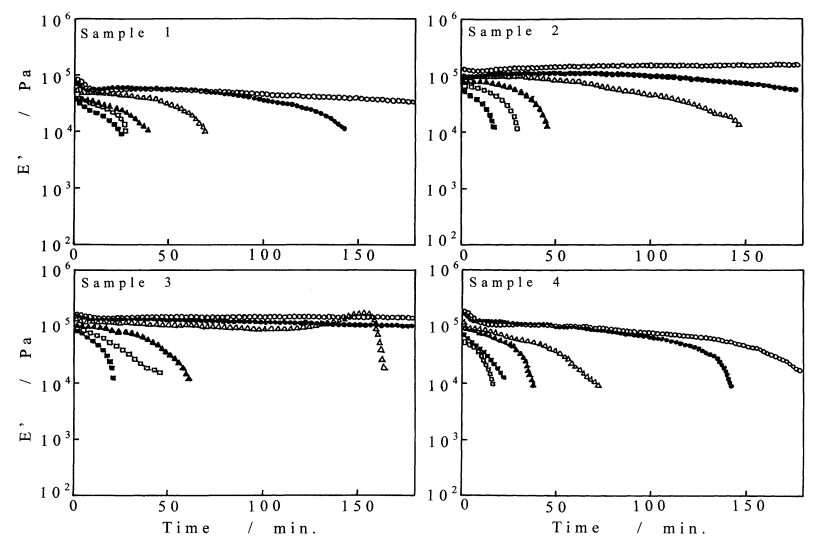

Fig.1 Dependence of the dynamic modulus on time. Vibration amplitude $30 \mu \mathrm{m}$, frequency $10 \mathrm{~Hz}$. (O), $240^{\circ} \mathrm{C},(\bullet), 250^{\circ} \mathrm{C},(\triangle), 260^{\circ} \mathrm{C}$ $(\mathbf{\Delta}), 270^{\circ} \mathrm{C},(\square), 280^{\circ} \mathrm{C},(\mathbf{\square}), 290^{\circ} \mathrm{C}$.

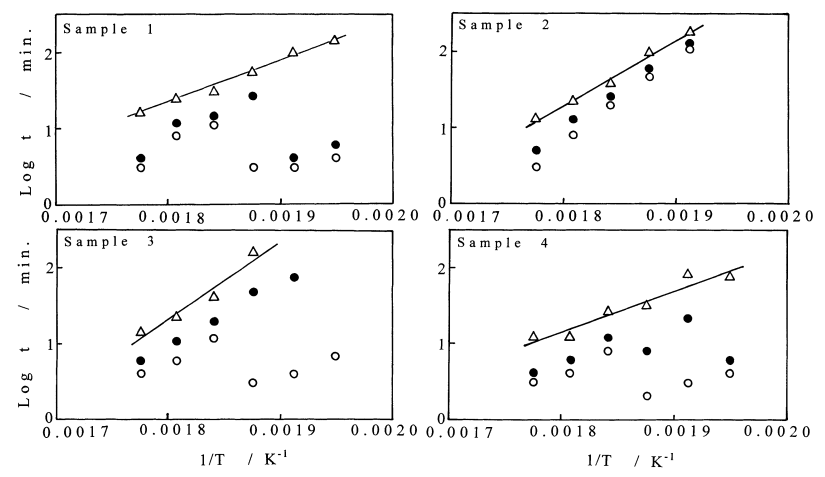

Fig.2 Dependence of the $\log t$ on $1 / T . t$ is the time from the start time of measurement till the time at which dynamic modulus become to be $0.9(O)$ or $0.8(\bullet)$ or $0.5(\Delta)$ times of its initial value. 
の動的弾性率が $50 \%$ 低下する值に測定終了時間の $180 \mathrm{~min}$ 経過 しても達しなかったので図には明示していない. すべての フォームにおいて動的弾性率が $50 \%$ 低下寸る時間を $t$ min とし た場合で $\log t$ と絶対温度の逆数とは次式のような直線関係に あり，相関係数が 0.92 以上あった。

$$
\log t=A / T-B
$$

$$
A=5440 \sim 12500, \quad B=8.64 \sim 21.2
$$

また, Sample 2のフォーム試料においては動的弾性率が 10, 20\%低下寸る場合およびSample 3 のフォーム試料においては 動的弾性率が $20 \%$ 低下寸る場合にも $\log t$ と絶対温度の逆数と は 50\%低下時と同様な直線関係にあり，相関係数が 0.99 以上 あった. Fig.2より使用条件に合った耐久時間を設定して温度 を求めることにより耐熱温度とすることができる．時間を $10^{2} \mathrm{~min}$ とした時の温度を耐熱温度とすれば, Sample 2 の場合 における耐熱温度は(2)式より動的弾性率が10\%低下する場合 において $252^{\circ} \mathrm{C}$, 動的弾性率が $20 \%$ 低下寸る場合において $254^{\circ} \mathrm{C}$, 動的弾性率が $50 \%$ 低下寸る場合において $258^{\circ} \mathrm{C}$ となり, 動的弾性率が $20 \%$ 低下寸る場合と $50 \%$ 低下寸る場合とは大き な差がないので動的弾性率が $50 \%$ 低下寸る場合における温度 を耐熱温度としても差し支えないと考えられる．他のフォー 厶試料において動的弾性率が $50 \%$ 低下寸る場合の而熱温度は Sample 1 が $247^{\circ} \mathrm{C}$, Sample 3 が $263^{\circ} \mathrm{C}$, Sample 4 が $238^{\circ} \mathrm{C}$ となり, Sample 3の耐熱温度がもっとも高い.

\section{4. 結 論}

硬質ポリウレタンフォームにおいて粘弾性測定器により 圧縮モードで動的弾性率の温度，時間特性を明らかにして， 耐熱性の評価方法に関する検討を行った。 フォーム試料の動 的弾性率の時間特性から独立気泡の内圧の影響をうけたス ケルトンの変形に対する抵抗の変化により動的弾性率は時 間とともに徐々に小さくなり，温度が高くなるほど動的弾性 率の時間に対する低下率は大きくなる. さらに，フォーム試 料における動的弾性率の時間特性から, 動的弾性率が $50 \%$ 低 下寸る時間を $t$ とした $\log t$ と絶対温度の逆数は直線関係にある ことがわかった. フォーム試料において $\log t$ と絶対温度の逆
数との関係式より耐久時間を設定して動的弾性率が $50 \%$ 低下 する場合における温度を求めることにより耐熱性の評価が できる。

謝辞 本研究を進めるに当たり，フォーム試料の提供をし ていただいたイノアックコーポレーション株式会社に謝意 を表します.

\section{REFERENCES}

1) Kurita S, Tagatani M, Nippon Gomu Kyokaishi, 55, 159 (1982).

2) Shimizu T, Koshiro S, Yamada Y, Nippon Gomu Kyokaishi, 69, 420 (1996).

3) Nakazato K, Fukudome H, Iwao A, Jidosha Gijutsu, 49, 6, 39 (1995).

4) Miyamoto M, Nihon Setchaku Gakkaishi, 35, 280 (1999).

5) Hatta H, Udagawa A, Higuchi K, Yokota R, Sugibayashi T, Zairyo, 48, 49 (1999).

6) Adachi H, Hasegawa T, Kobunshi Ronbunshu, 57, 552 (2000).

7) Adachi H, Hasegawa T, Nihon Reoroji Gakkaishi, 29, 95 (2001).

8) Adachi H, Hasegawa T, Nihon Fukugozairyo Gakkaishi, 27, 201 (2001).

9) “Kouza Reoroji”, ed. Nihonreorojigakkai, Koubunshikankoukai, Kyoto (1996), pp.111-119.

10) Furukawa H, Higashiyama K, Yamamoto T, Jidosha Gijutsu, 49, 6, 24 (1995).

11) Jinen E, Suzuki M, Nakamura S, Kobunshi Kagaku, 28, 659 (1971).

12) Qiu J, Kawagoe M, Mizuno W, Morita M, Kobunshi Ronbunshu, 56, 255 (2000).

13) Qiu J, Nihon Kikai Gakkai Ronbunshu A, 68, 266 (2002).

14) Ishisaka A, Kawagoe M, Miyano Y, Nihon Kikai Gakkai Ronbunshu A, 68, 611 (2002).

15) Ohnishi T, Nippon Gomu Kyokaishi, 75, 268 (2002).

16) Adachi H, Hasegawa T, Nihon Reoroji Gakkaishi, 31, 109 (2003). 